\title{
The Twilight Language of Svānubhava Gìti by Nārāyaṇa Guru - Analysis of Selected Stanzas in the Light of Tirumantiram and Other Tamil Literary Sources
}

\author{
Hanna Urbańska \\ Institute of Classical, Mediterranean and Oriental Studies \\ Indian Philology and the Culture of India \\ University of Wrocław
}

\begin{abstract}
This paper attempts to interpret selected stanzas from the work of Nārāyaṇa Guru (1854-1928), a South Indian philosopher and social reformer from Kerala. The ancient yogic concept of kundalini śakti presented by Guru in his short poem the Kundalinī Päțt (The Song of the Kundalini Snake) also appears in Svānubhava Gīti - Lyric of Ecstatic Self-Experience (among others in stanza 41 and 42) - the Malayalam hymn which represents the nirguna-poetry describing the mystical experience. An analysis of each motif included in the stanzas mentioned above in the light of Tamil Śaiva tradition (among others Tirumantiram by Tirumūlar) shows that not only the kuṇalinī concept could have been adopted from Tamil tradition; Nārāyana Guru seems to apply the very same style of presentation of yogic experiences to his works by means of the twilight language. A comparative analysis of Svānubhava Giti and Tirumantiram allows us to better understand the concept of the Śiva-Śakti relations presented by Guru.
\end{abstract}

Key words: Svānubhava Gīti, Nārāyaṇa Guru, Tirumantiram, kuṇ̣̂alin̄̄, twilight language Słowa kluczowe: Pieśń o samorealizacji, Narajana Guru, Tirumantiram, kundalini, język metafor 


\section{Introduction}

In this paper I will attempt to interpret selected stanzas of the Svānubhava Giti (Lyric of Ecstatic Self-Experience - henceforth SG) by Nārāyaṇa Guru - a South Indian philosopher and social reformer from Kerala. ${ }^{1}$ In his mystical poem, Nārāyaṇa Guru includes mysterious descriptions of Siva and Śakti, whose union becomes the goal of yogic practice. ${ }^{2}$ Three commentators suggest interpreting this idea in the context of Kundalinī Yoga, which introduces the concept of kundalinī sakti, a serpent power which is coiled at the base of the spine in a state of sleep. The Tantric Yoga of the South adopted and revised the methods of Patañjali (Aștānga Yoga) and added the practice of rousing the kundalini, which means directing it upwards through the sușumna channel - the spinal or central column within the human body - to the crown of the head, where the sahasrāra cakra (lotus) blooms. ${ }^{3}$ It is worth comparing the stanzas of SG mentioned above with the relevant passages of the Tamil Śaivite work - the Tirumantiram (TM) by Tirumūlar. ${ }^{4}$ An attempt to interpret these stanzas by means of the

${ }^{1}$ Nārāyaṇa Guru (1854-1928), a South Indian philosopher, saint and social reformer from Kerala. He applied the basic aspects of his philosophical system which comprised Vedānta, Yoga, Sāmkhya, Śaivism etc. to bring about radical social transformations in Kerala. Nārāyaṇa Guru did not write any commentaries on canonical texts like Upanișads or Bhagavad Gìta; instead he created - in three languages (Malayalam, Sanskrit and Tamil) - original works classified into five groups: 1. Devotional hymns; 2. Works of moral importance; 3. Translations from Sanskrit and Tamil; 4. Prose works; 5. Philosophical works (V. Jayakumar, Sree Narayana Guru. A Critical Study, New Delhi 1924; M. Kumaran, The Biography of Sree Narayana Guru, Varkala 2014).

Svānubhava Gīti - Lyric of Ecstatic Self-Experience - is a devotional hymn composed by Nārāyaṇa Guru in the Malayalam language around 1984 in Aruvippuram. The first three sets of ten verses were separately named Anubhūti Daśakam (Ten Verses on Ecstatic Self-Experience), Prapañcaśuddhi Daśakam (Ten Verses on Clarity about Phenomenal World), Paramaśivā Cintā Daśakam (Ten Verses on Reflections on Parama Śiva). The rest of the work was called Vibhu Darśanam (Visualising the All-pervading God). Forty verses are missing after ten verses of this section [hence editions offer two kinds of numeration: 41 or 81, 42 or 82 etc.]. Another name by which this work is known is Amrtataraingini (The River of Immortal Elixir) (M.N. Prasād, Narayana Guru. Complete Works, New Delhi 2006, p. 83).

${ }^{2}$ In several stanzas of Svānubhava Gīti (among others 41, 42, 45, 46, 47 and 49), Nārāyaṇa Guru introduces mystical description of the union of Śiva and Śakti by means of metaphorical language. In this paper I will examine two stanzas of Svānubhava Gīti: 41 and 42.

3 "Teachers in the south did not develop a separate system based on Śaiva doctrines contained in the Āgamas, but revised the already prevalent system of Patañjali" (B.N. Pandit, Specific Principles of Kashmir Śaivism, New Delhi 1997, p. 93).

${ }^{4}$ Nārāyaṇa Guru was proficient in Tamil language and literature - as well as in Malayalam and Sanskrit - (N.C. Yati, Narayana Guru, New Delhi 2007, p. 13; M. Balachandran, Sree Narayana Guru. A Comprehensive Study, Varkala 2015, pp. 20-21). He studied yoga with notable ascetics such as Cattambi Svāmikạ and Taikkātṭ Ayyāsvāmikaḷ, a novice of Śiva Rāja Yoga based on Tirumantiram, which is said to be the first exposition of Śaiva Siddhānta in Tamil Nadu (G.V. Tagare, Śaivism. Some Glimpses, New Delhi 1996, p. 60) and "the earliest representation of Tantric thought and practice among the Tamil cittars [Siddhas]" (D.R. Brooks, Auspicious Fragments and Uncertain Wisdom: The Roots of Śrividyā Śäkta Tantrism in South India [in:] The Roots of Tantra, K.A. Harper, R.L. Brown (eds.), Albany 2002, p. 57). The author of Tirumantiram - Tirumūlar - is described in the Periya Purānam by Sēkkilār as a Śaivite yogi born in Kailāsa mountain, who travelled to Tamil Nadu and composed Tirumantiram within 3000 years (S. Ponnuswamy, Sekkizhar's Periya Puranam, Chennai 2015, pp. 252-255). According to another version, Tirumūlar was born in Tamil Nadu and travelled to Mount Kailāsa (K.R. Arumugam, Introduction [in:] The Yoga of Siddha Tirumular. Essays on the Tirumandiram, T.N. Ganapathy, K.R. Arumugam, 
so-called twilight language (sandhyābhāșā) of Tirumantiram by Tirumūlar as well as of works of other Tamil Siddhas (metaphorical language of deceptive simplicity, in which the most sacred is hidden in the form of the most ordinary $)^{5}$ shows that comparative analysis of these two works - the Tamil Tirumantiram and the Malayalam Svānubhava Gìti - can be an efficient instrument for research into nirguna poetry, presenting indescribable moments of self-realisation. It is worth emphasising here that Nārāyaṇa Guru - just like the author of TM - avoids the term kuṇdalinī or cakra (i.e. the energy centre) while introducing sandhyābhāṣā in his works.

The supreme reality, representing nirguṇa state and transcending all tattvas (principles of the universe) as well as the highest cakra (sahasrāra), has been described in Tirumantiram as Parāparam that has neither beginning nor end; when consorting with Parāparai (feminine gender), it gave birth to Param (Para Śiva) and Parai (Parā Śakti). ${ }^{7}$ From the union of Param and Parai [para-]nāda was born. When para-nāda united with para-bindu, Ś

G. Anand (eds.), Quebec 2006, pp. 8-9; T.N. Ganapathy, Life Sketches of the Siddhas [in:] The Yoga of the 18 Siddhas. An Anthology, T.N. Ganapathy (ed.), Quebec 2004, p. 21). It is worth emphasising here that the concept of kundalini imagined as a dancing snake (ătunna pāmb), mentioned by Guru in another poem, Kundalinī Pātț (The Song of the Kundalini Snake), was borrowed from the Tamil songs of Pāmbātți Siddhar (T.B. Nair, Jñannakkațal (Malayalam Mertical Version of Jnanakkovai, in Tamil), Trivandrum 1974, pp. 48-65; cf. T.B. Siddhalingaiah, Pāmbātțiccittar. Selections from Dance, oh! Snake! Dance [in:] The Yoga of the 18 Siddhas..., pp. 485-513).

${ }_{5}$ According to Ganapathy, twilight language means that "the ideas may be explained either by the light of the day or by the darkness of the night" (T.N. Ganapathy, A Curtain Raiser [in:] The Yoga of the 18 Siddhas..., p. 3). To express their mystical experience and to conceal the spiritual doctrines of Kundalinī Yoga from the uninitiated, the Siddhas used a paradoxical language - "a clothed language in which the highest truths are hidden in the form of the lowest, the most sacred in the form of the most ordinary. The meaning of the poems operates at two levels - one, the exoteric and the linguistic, the other, the esoteric and the symbolical" (idem, The Twilight Language of the Tirumandiram [in:] The Yoga of Siddha Tirumular..., pp. 295-297).

${ }^{6}$ The cakras, i.e. energy centres pierced by kundalinī śakti during her ascension within suṣumnā channel, are: mūlädhāra, situated at the base of the spine; svādhișthāna - located below the navel, manipüra - behind the navel, anāhata - the heart cakra, viśsddha - the throat cakra, ajjña -located in the space between the eyebrows. The highest point is called sahasrära cakra, located on the top of the head.

7 "Parāparam that has neither Beginning nor End, in pure Consciousness consorted with Parāparai and in that Light Pure arose Param; and from union of Param with Parai immaculate was Nāda born //381// Nāda united with Bindu; from the union of Nāda-Bindu was Siva and Śakti born; from them evolved the three - Jñāna, Kriyā and Icchā; Icchā then sought union with Bindu" //382// (Tirumantiram by Tirumular, B. Natarajan (transl. and ed.), Madras 1991, p. 92).

${ }^{8}$ Cf. Malayalam commentary (C.K.G. Nāyar, Tirumūlanāyanār Tirumantram, Kottayam 2007, p. 140): parāparam - paramāyayilninnum vimuktanāyavan; param - parāśakti - "parāparam - the one who is released from/free[d] from para, māya [i.e. all levels/aspects of śakti]; param means parāśakti" [i.e. transcendental one]. In TM 82285 Paramparan (Paräparam) is defined as superior to Paramam and Param. Compare also Śabdatārāvali (Malayālam Nighaṇtu), K.G. Padmanābhapiḷ!a (ed.), Kottayam 2011, pp. 1172, 1177); "The neuter Parāparam leaves no idea of Śakti, or female energy" (H. Israel, Religious Transactions in Colonial South India. Language, Translation, and Making of Protestant Identity, New York 2011, p. 94). The Siddhas are described as unbelievers of personal deity - for them there is an "It" or "Thatness" - Parāparam (P.S. Somasundaran, Maccamuñi. Kärana Jñānam-10 (Source of Wisdom) [in:] The Yoga of the 18 Siddhas..., pp. 164-165). Ganapathy interprets the term Paräparam as impersonal conception - "It" or "Thatness", "Suchness" (T.N. Ganapathy, A Curtain Raiser, p. 1). 
creation agrees completely with the monistic view of Kashmir Śaivism. ${ }^{9}$ Nandakumar differentiates between meditation of the saguna and nirguna kind; in the former case, one concentrates upon the form of Śakti (parā-dhyāna), whereas with the latter one meditates upon the concept of transcendent Śivam-parāpara-dhyāna. ${ }^{10}$

\section{Interpretation of motifs included in stanzas 41 and 42 of SG in the light of Tamil literary sources}

As mentioned above, in several stanzas of SG $(41,42,45,46,47,49)$ Nārāyaṇa Guru introduces the concept of a golden, beautiful or flowery creeper (ponninkoți; püinkoti), which represents the other side (bhāgam) of Śiva, and which is inseparably connected with Him and imagined as covering the Primeval/Original Tree or mounting the Silvery Mountain (SG 46). In this paper I will try to interpret two stanzas of SG: 41 and 42.

\section{A. Stanza 41}

onnumariñ̃̃̄layyō ninnuṭe līlāviśéșamitu valutē /

ponninkotiyoru bhāgam tannil currippațarnna tanimaramē // 41 / 81 //

How great is your particular divine game! Nothing of that is comprehended by me - what a pity!

The golden creeper entwines you as [an inseparable] part of you, o the Primeval Tree!

The golden creeper (ponninkoti) is described as entwining the Primeval Tree (tanimaram), constituting an inseparable part of It. According to commentators, the climbing vine represents the Goddess Pārvati and the part (bhāgam) can denote the left side, ${ }^{11}$

\footnotetext{
${ }^{9}$ G. Anand, T.N. Ganapathy, Monistic Theism of the Tirumandiram and Kashmir Saivism [in:] The Yoga of Siddha Tirumular..., pp. 489-492.

10 P. Nandakumar, Tirumūlar Dhyānam-20 (Meditation) [in:] The Yoga of the 18 Siddhas..., p. 75.

${ }^{11}$ ponvallipōle saundaryamulḷa pārvati - "Pārvati beautiful like the golden creeper"; oru bhāgam - oru vaśatt; ițatuvaśatt - "On the one side - on the left side” (T. Bhāskaran, Śrīnārāyaṇaguruvinre Sampürnakrtikal, Kozhikode 2015, p. 332). In the Ardhanārïśvara concept, the left side is occupied by the Goddess/Śakti, and the right one by Lord Śiva. In the Spanda doctrine of Kashmir Śaivism, "this Goddess is called Vyomaveśvarī, Vyomeśvarī or simply Vāmeśvarī. She is the Goddess (iśvarī) who resides in the sky (vyoman) and emits, spits out or vomits (Sanskrit root vam) the universe of personal experience out of the universal experience of the absolute [...]. As Her name Vāmā (meaning 'left', 'perverse' or 'contrary') indicates, She accounts for a reversal or, more precisely, a 'double-reversal' within the absolute. For the unenlightened, She is the source of diversity and, as such, She is the potential cause of bondage - the "reverse' of Śiva's state of unity and freedom" (M.S.G. Dyczkowski, The Doctrine of Vibration. An Analysis of the Doctrines and Practices of Kashmir Shaivism, Delhi 1987, pp. 129-130). It seems that a similar concept can be found in Ätmōpadéśa Śatakam (One Hundred Verses on Self-Instruction) by Nārāyaṇa Guru: arivilirunnorahantayādyamunțāy varumitinōtoridanta vāmayāyum/varumiva raṇtulapan்nal pōle māyāmaramakhilam marayeppațarnnițnnu //51// ("Having existed within consciousness, the I-ness, in the beginning, arises; together with I-ness This-ness comes as its counterpart/on the left side. These two, while coming, like creepers cover completely the māa $\bar{a}$ 's tree to conceal it").
} 
the creeper of prāna consisting of tejas,${ }^{12}$ or the $m \bar{a} y \bar{a}$-creeper identical to Pārvati; ${ }^{13}$ the golden colour indicates the transformation of the lower sakti into the higher one, as stated by Prasād: "That golden creeper is nothing else but Pārvati. As soon as Kāli becomes transformed into Gauri, such a golden colour can be obtained." 14 The Purānic version of the concept of one Śakti operating on the lower and the higher level (parāa-aparā śakti) presents Pārvatī addressed by Śiva as Kālī, the "black goddess." When Pārvatī came to take her bath in the Gangā, a new goddess was born from the five sheaths of her body, called Kauśikī, while Pārvatī remained herself as Kālī. ${ }^{15}$ The Evergreen Tree mentioned above represents Ardhanārísvara ${ }^{16}$ kêvalam state ${ }^{17}$ or the Lord being fixed like a tree. ${ }^{18}$ The idea of a golden creeper (porkoti) symbolising Śakti appears in Tirumantiram; the golden colour has been associated here with the creeper symbolising the viśuddhi (viśuddha) cakra - the cakra of the throat being the place of transformation of the poison into amrta, and with the ājñ $\bar{a}$ and sahasrāra cakras, representing the moonregion of the head. The body-space below the throat stands for darkness or ignorance; when the lower energy is sublimated above the viśuddha cakra, it becomes transformed into higher energy. ${ }^{19}$ The top branch of the mystic tree represents the sușumnā channel;

12 tējōmayamāya prānnalata. acañcalavum ānandaghanavumāya oru bōdhattinulliliānu uṛappuḷ̣a marattil vaḷlicurrippinayum pōle $\bar{\imath}$ prānan prasarikkunnatennum teliyum, atōte acañcalabōdhattil śaktispandanam prāṇarūpam kaikoṇt uṇtākkiyalikkunnatān i prapañcalīla - "The creeper of prāna consisting of light/brightness. That präna flows like a couple of creepers entwining the tree being the strength/ stability, within immovable consciousness, which is condensation of bliss; simultaneously - when within that immovable consciousness the pulsation of sakti, having assumed the form of prāna, rises, the divine game being the phenomenal world becomes destroyed" (B. Nāyar, Śrīnārāyaṇa Gurudēvakrtikal. Sampürna Vyākhyānam, vol. 1, Thiruvananthapuram 2010, pp. 418-419).

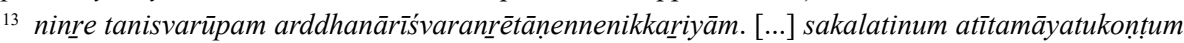
marronninōtum upamikkānillāttatukoṇtum [...] māyavum kalarāttatukoṇtum nī taniyān. prāpañcikajīivitamākunna māyālatakk pațarnnukayąuvān tāinnāyirikkunna maravumānn n̄ - "I know that your genuine essential nature is that of Arddhanāriśsvara. You are the sole/pure/genuine (being) because not mixed with māyam (falsehood or illusion), and because you are incomparable to anything else and transcendent to everything. You are the tree which becomes support which is to be climbed and entwined by the $m \bar{a} y \bar{a}-$ creeper representing worldly existence" (M.N. Prasād, Nārāyaṇaguru. Svānubhavagīti, Varkala 2002, pp. 127-128).

${ }^{14}$ at pārvvatiyallāte marrāāāṇ. kāḷ gauriyāyi māriyappōl kaivannatāyirikkām à sūvarṇnacchavi (ibidem, p. 128).

${ }^{15}$ Devī Māhātmya 5.83-88. Cf. P. Kumar, Śaktism in India (With Special Reference to the Purānic Literature), New Delhi 2012, p. 52; Devī Māhātmyam. In Praise of the Goddess, transl. and com. D. Kālī, Delhi 2010, p. 119.

${ }^{16}$ ninre tanisvarūpam arddhanārišsvaranrēetānennenikkariyām - "I know that your genuine essential nature is that of Arddhanāriśvara" (M.N. Prasād, Nārāyanaguru..., p. 127).

17 kèvalamāya maramē - "O tree being the kēvalam state" (T. Bhāskaran, op. cit., p. 332).

${ }_{18}$ āśrayamāyi maram pōle uraccu nilkkunna allayō bhagavan - "The Lord remaining fixed like the tree being the support [for the creeper]” (B. Nāyar, Śrīnārāyaṇa Gurudēvakrtikal..., p. 418).

19 "When the sex-energy (śukla) is directed below in this body-space it is dark. When the suklaenergy is sublimated above the throat, it stands for amrta and it illuminates the body-space above the throat" (T.N. Ganapathy, The Yoga of Tirumandiram [in:] The Yoga of Siddha Tirumular..., p. 215). Tirumūlar interprets the famous myth about Śiva drinking the poison in the context of Kundalinī Yoga: according to him, the poison stands for semen; which, when wasted, brings death. Semen when it is preserved and directed upwards becomes nectar. This conversion is possible thanks to the igniting of the kundalini fire. "The region of space, represented by a ajjña and sahasrāra (which symbolises the transcendental space - paraveli) alone is conductive for Yoga. To mark the boundary line, the throat of the Lord 


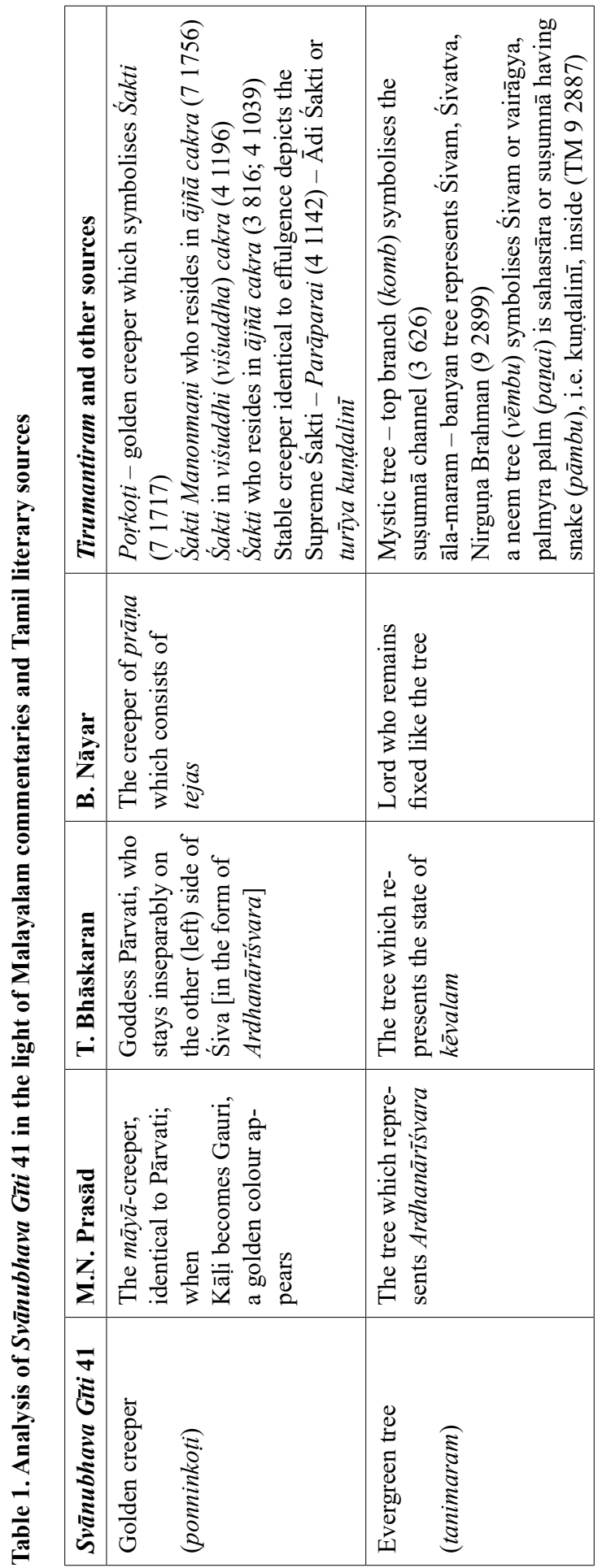


in such a context, the golden creeper represents kundalini śakti rising in the central channel above the viśuddha cakra, within the moon-region of the body. It is mentioned in TM 92887 that on the neem tree representing vairāgya arises the palmyra palm symbolising sușumnā or sahasrāra, which has a snake (kuṇdalinī śakti) inside. TM 4 1142 depicts the Supreme Sakti (Parāparai) abiding in the Supreme One (Paraman $)$ and imagined as the ever-enduring/firm or powerful liana (tinkoti) being the effulgence (cōti) illuminating the whole world. As the term cōti appears in TM 2381 in relation to the same (Supreme) aspect of Śakti, ${ }^{20}$ the creeper identical to effulgence illuminating the whole world can also be referred to the highest aspect of kundalinī (called turīya or mahā kuṇụlinī in Laya Yoga). ${ }^{21}$

\section{B. Stanza 42}

The Primeval Tree has been identified in the consecutive stanza 42 with the Primeval Mountain, which Prasād and Bhāskaran explain to be Kailāsa Mountain: ${ }^{22}$

tinamaramē, tanaliniȳi ninkani kalalinayen talaykku pūvaṇiyē,

kanakakkoṭi koṇțāțum tani māmalayē, yitentu kaṇmāyam? // 42/ 82 //

O the Primeval Tree, your fruit will become my shelter in the future,

Your feet ${ }^{23}$ are the flower-ornament for the top of my head; ${ }^{24}$

$\mathrm{O}$, the Primeval Great Mountain dancing with the golden creeper - it is the great magic indeed!

was blackened" (K.R. Arumugam, Śaivism as Conceived in the Tirumandiram [in:] The Yoga of Siddha Tirumular..., pp. 130-132).

${ }^{20}$ Parāparai in TM defines the Supreme Śakti consorting with Parāparam - the Supreme Reality being pure consciousness. From the union of these two aspects Param (Para Śiva) and Parai (Parā Śakti) are born (TM 2381 ).

${ }^{21}$ According to the Laya Yoga system, in dhruva-mandala situated above sahasrāra the supreme kundalin̄ exists in the form of Śankhinī being in $3 \frac{1}{2}$ coils: the first coil is supreme bindu (para-bindu), the second one supreme nāda (para-nāda), the third one Śakti and the half coil is Sakala Siva. "At the $n \bar{a} d a$ level, when kundalini is towards Supreme Siva, sound is completely coiled into her. When supreme kundalin̄ is at the Siva-Śakti level, Śiva shines forth in kundalinī. Thereafter kundalinī is in union in supreme love with Parama Siva - infinite Consciousness. This occurs at the Sakala Siva stage. Finally kundalini in supreme union becomes one and the same with Parama Siva" (S.S. Goswami, Layayoga. The Definite Guide to the Chakras and Kundalini, Vermont 1999, p. 122).

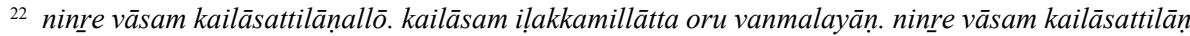
ennu parayunnatinēkkāl tattvaparamāyi kūțutal śari, n̄ tanneyān à māmala ennu karutunnatān "Your abode is Kailāsa mountain. Kailāsa is an immovable great mountain. More correct and truthfully than saying that you dwell in Kailāsa Mountain is to consider you to be that great mountain yourself" (M.N. Prasād, Nārāyanaguru..., p. 130). tani malayumānn, kailāsaparvatam (atiluḷla śivaneyum kurikkunnu) - "is the Single/Original Mountain, Kailāsa Mountain (it aims at Śiva dwelling in the mountain)" (T. Bhāskaran, op. cit., p. 333).

${ }^{23}$ samsāra tāpamērruvalayunna enikkini orāśrāsam avițatte kārunyam nịañ̃ãa pādañnaltanne "Feet filled with your mercy/compassion being in future consolation for me who is distressed by the risen pain of saìsāra" (C.K.G. Nāyar, Tirumūlanāyanār..., p. 419).

${ }^{24}$ enre talayil pu cüti kulirppikkaṇe - "The flower should give consolation/make cool the heat on my head" (ibidem). 
The concept of the mountain dancing with the golden creeper has been interpreted by Prasād as the process of manifestation in the form of the phenomenal world, ${ }^{25}$ whereas Nāyar sees here the flow of prāna spreading within the body. ${ }^{26}$ According to Bhāskaran's interpretation, it symbolises the final union of Śiva and Pārvati. ${ }^{27}$ As a result of dance, the devotee is able to obtain the ripe fruit which is Siva's mercy or grace - arul, which becomes his shelter. ${ }^{28}$ It is worth emphasising here that the Kailāsa in Kuṇualinī Yoga represents the element of the sahasrāra cakra and suggests the stage of final union of Śiva and Śakti. ${ }^{29}$ In Śaiva Siddhānta, Siva's feet placed on the devotee's head become the symbol of final realisation attained in sahasrāra cakra and beyond, in dhruva-mandala. ${ }^{30}$ On the other hand, the shelter given by the ripe fruit as well as the dance performed by Siva and Śakti can be referred to the phenomenal world and $m \bar{a} y \bar{a}$ sphere. ${ }^{31}$

We can find the following interpretation in the Tirumantiram: the golden creeper/ flowery twig - kundalinī śakti joins or ascends Meru Mountain - in the void representing the Supreme Reality (pure consciousness divested of all matter), or sways on the top of Meru, which is the symbol of the susumnā channel and Siva Himself. The Dance of Siva can be experienced as a result of yoga practice in the $\bar{a} j \tilde{n} \bar{a}$ and sahasrāra cakras, in the space above the head, called dvādaśanta, beyond and beyond (appuram). The plump fruit being the bliss of sahasrāra or Śivatva can be obtained at the top of the mountain (malai-mēl), symbolising Kailāsa or the void above

${ }^{25}$ kanakakotiyōt cēernn onnāyirunnu konț nātakamātunna. nī illakāte uraccu nilkkunnu, śaktiyute sānniddhyam nimmittam ninnil sakala prapañcanātakañnaḷm sadā națannu konțirikkukayum ceyyunnu - "Dancing while joined entirely into one with the golden creeper. You always remain fixed and immovable, because of the proximity of śakti you make constant movements and perform dance being the whole phenomenal world within you" (ibidem, p. 129).

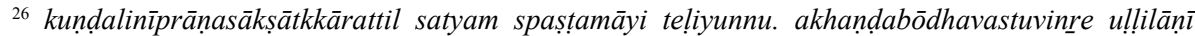
prānan prasarikkunnat. bōdhavastuvile ānandam prānaprasarattil sarvatranịaññanubhavappețkay um сеyуипn - "In the realisation of kundalini prāna the ultimate reality clearly reveals itself. That prāna flows within the substance being undifferentiated consciousness. Within that consciousness, during the flow/rise of präna, bliss can be experienced, having spread everywhere" (ibidem, p. 420).

${ }_{27}$ āhlādapūrvam svīkarikkunnat kanakalatapōlullla pārvati - "Receiving with joy as a wife Pārvati being like a golden vine/creeper" (T. Bhāskaran, op. cit., p. 333).

${ }^{28}$ ninre kanivākunna kani (palam) - "The fruit (the ripe fruit) being your compassion/mercy" (ibidem); kanivākunna kani, karunyamākunna palam - "The fruit being compassion, the ripe fruit being mercy” (M.N. Prasād, Nārāyanaguru..., p. 129).

${ }^{29}$ Kailāsa mountain as an abode of Siva in the Laya Yoga system is said to be situated in the form of a triangle within sahasrāra, the moon-region, or represents sahasrāra itself (A. Avalon, The Serpent Power being the Shat-Chakra-Nirüpana and Pādukā-Panchakā, Madras 1950, pp. 149-153).

${ }_{30}$ TM 51437 states that one who attains the shower of grace of Paraparai - the Supreme Sakti - by the holy feet (pādattāl), is able to become Śivam (i.e. Parāparam) - the supreme reality. Cf. H.W. Shomerus, Śaiva Siddhānta. An Indian School of Mystical Thought, New Delhi 2000, p. 292: "If the organs of the body are destroyed, the Átmanbōdha will rise up by the sound (Paranāda) of noisy foot ornaments (Para$v i n d u$ ) to unite itself with Sivabodha and be merged in it. And when that happens the Supreme who stands at the end of the sound will appear, in jñanna community of his Śakti, and loving you in this manner will make you one with himself." Parabindu and Paranāda represent the sphere situated above sahasrāra, called dhruva-maṇdala. In Śiva Śatakam 27 - another hymn composed by Nārāyaṇa Guru - Parama Śiva becomes the one who bestows the grace through His divine feet placed on the devotee's head.

${ }^{31}$ samsāra tāpamērruvalayunna enikkini orāśvāsam avițatte kārunyam nịañãa pādañnaltanne (B. Nayār, Śrīnārāyaṇa Gurudēvakrtikal..., p. 419). 


\begin{tabular}{|c|c|c|}
\hline 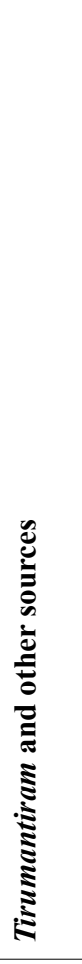 & 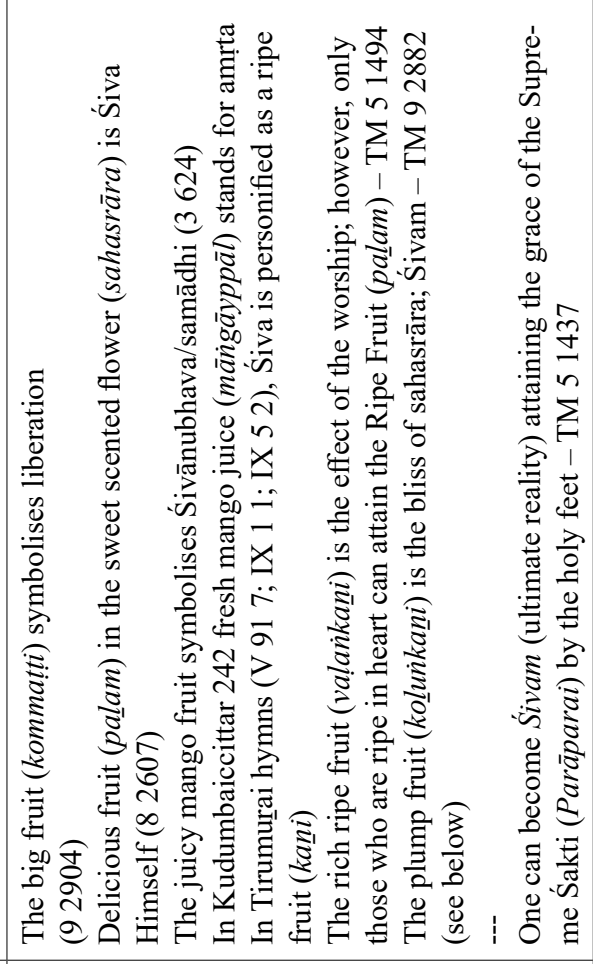 & 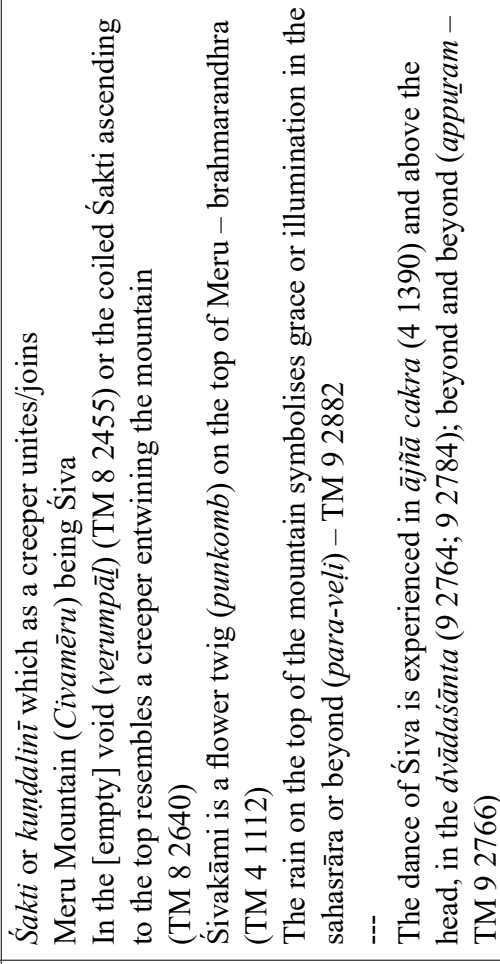 \\
\hline 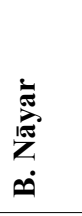 & 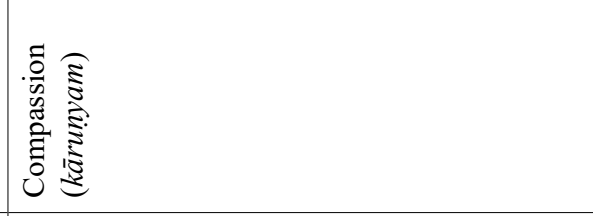 & 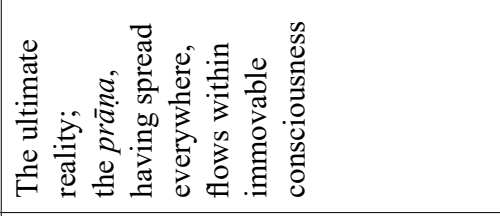 \\
\hline 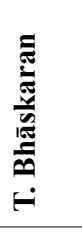 & 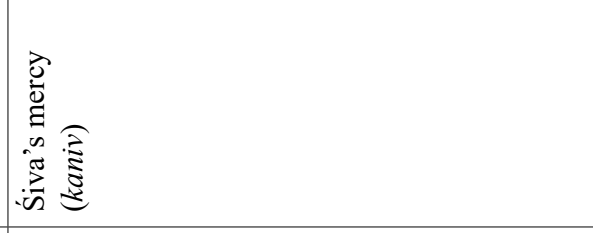 & 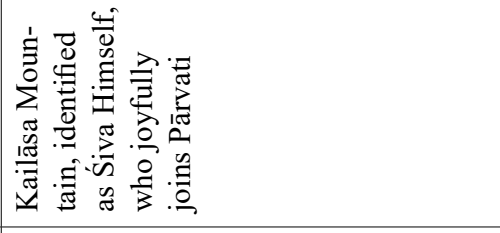 \\
\hline 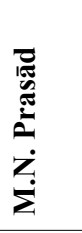 & 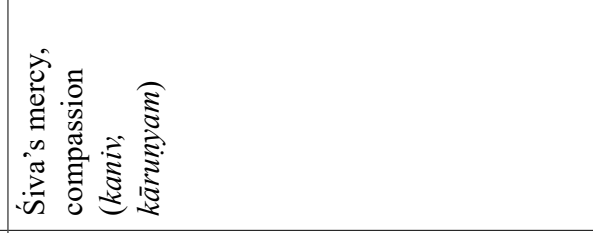 & 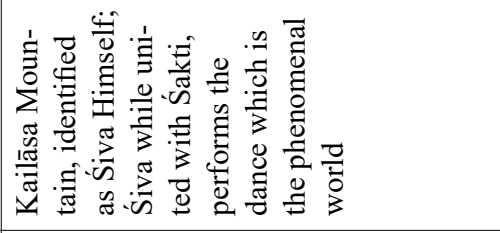 \\
\hline 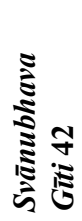 & 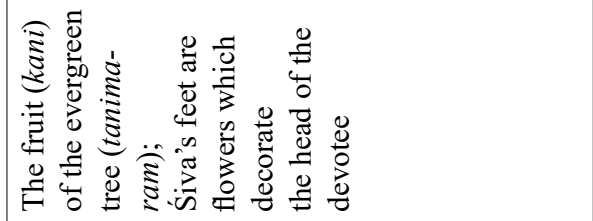 & 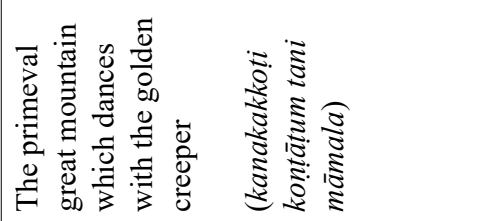 \\
\hline
\end{tabular}


(para-veli). TM 51494 differentiates between valankani (rich ripe fruit) and palam (the ripe fruit); the latter symbolises the result of internal worship and yogic practice, and can be obtained by those who are ripe in their hearts.

Nārāyana Guru mentions the divine dance of Siva in such a context in the $99^{\text {th }}$ stanza of another hymn devoted to Śiva - the Śiva Śatakam (One Hundred Stanzas Devoted to Śiva): $:^{32}$

amaravāhinipon்inarum tiraykkamaramennakaṇakku pațan்naḷm

samarasattil viricc aravainnaḷọtamarum accițayātịațukkaṇam // 99 //

Please approach me while dancing, You - adorned with matted hair,

Surrounded by snakes, spreading up their hoods harmoniously ${ }^{33}$

Like a stern of a ship [moving towards/against] waves lifted up by the river bringing immortality.

The dancing Siva and the spread of snake-hoods in one and the same shape above the yogi's head symbolises the ascent of kundalini sakti up to the higher regions, where the yogi can experience the dance of Śiva and unite with the Lord in the moon region, the sahasrära lotus and beyond. The image of the spread of snake-hoods resembles the sahasrära lotus, described as standing with its face downwards in the void region where there are no nāḍīs - channels, resembling an umbrella spreading over the yogi's head. ${ }^{34}$

In the twilight language of Tirumantiram, the ripe fruit denotes liberation - mokșa - or attaining Śivatva or Sivam - the supreme state without any limitation or attributes. ${ }^{35}$

32 Śiva Śatakam (One Hundred Verses Devoted to Śiva) is a devotional hymn composed by Nārāyaṇa Guru in the Malayalam language in 1884.

33 Tirumantiram describes that dancing five-hooded snake, which symbolises the enjoyment of the senses, as making a single hood-pose, which stands for the control of the senses, withdrawal of the senses from their objects and performing tapas (TM 6 1621). There is an image of a five-hooded snake spreading its hoods over Śiva's head in the Śaiva tradition (cf. "The nāga is won over by the word of the Awakened One and lends him his support. Such is the king of the $n \bar{a} g a$, Mucilinda, who is represented in numerous sculptures standing erect behind the Buddha protecting his head from the elements by spreading his hood like a canopy or sunshade," L. Silburn, Kuṇdalinī. The Energy of the Depths. A Comprehensive Study Based on the Scriptures of Nondualistic Kasmir Saivism, Albany 1988, p. 18).

${ }^{34}$ The sahasrāra lotus is described as standing with its face downwards; it lies in the void region where there are no nādīis, resembling an umbrella spreading over the yogi's head (S.S. Goswami, op. cit., pp. 266-267).

${ }^{35}$ Tamil Śaiva Siddhānta makes a distinction between the use of the terms civan and civam; the former means Śiva, whereas the latter means supreme abstraction without any limitations or attributes (T.N. Ganapathy, Preface [in:] The Yoga of Siddha Tirumular..., pp. XVII-XVIII). 


\section{Conclusion}

The Malayalam hymns of Nārāyaṇa Guru, which represent the nirguna-poetry describing the mystical experience, can be interpreted in the light of the Tamil works (especially Tirumantiram) composed in twilight language. A comparative analysis of each motif included in the stanzas quoted above allows us to better understand the concept of the Siva-Śakti relations presented by Guru. He seems to apply the very same twilight language of Tamil Siddhas and to introduce the very same concepts and ideas presented in the form of the same metaphors. Almost each depiction of the golden creeper or the flowery vine symbolising Părvati entwining the great mountain or evergreen tree representing Śiva constitutes - in accordance with Nandakumar's interpretation - the description of meditation of saguna kind, during which one concentrates upon the form of Śakti (parā-dhyāna), and at the same time it contains elements characteristic of the description of meditation upon the concept of transcendent Śivam-parāpara-dhyāna. ${ }^{36}$ Svānubhava Gïti reflects the ideas depicted by sandhyābhāṣa of Siddhas who "were not devotees in the sense of idol-worshippers. They believed in a Supreme Abstraction. The recurrent use by the Siddhas of the word civam (an abstract noun [...] and the highest state of God, in which He exists as pure intelligence) in preference to the common term civan (meaning Siva), makes the point very clear." ${ }^{37}$

\section{Abbreviations}

TM - Tirumantiram

SG - Svānubhava Gīti

\section{Bibliography}

Anand G., Ganapathy T.N., Monistic Theism of the Tirumandiram and Kashmir Śaivism [in:] The Yoga of Siddha Tirumular. Essays on the Tirumandiram, T.N. Ganapathy, K.R. Arumugam, G. Anand (eds.), Quebec 2006, pp. 463-510.

Arumugam K.R., Introduction [in:] The Yoga of Siddha Tirumular. Essays on the Tirumandiram,

T.N. Ganapathy, K.R. Arumugam, G. Anand (eds.), Quebec 2006, pp. 3-44.

Arumugam K.R., Śaivism as Conceived in the Tirumandiram [in:] The Yoga of Siddha Tirumular. Essays on the Tirumandiram, T.N. Ganapathy, K.R. Arumugam, G. Anand (eds.), Quebec 2006, pp. 101-153.

Arumugam K.R., The Tirumandiram. Volume 5. Translation and Commentary [in:] The Tirumandiram. Translation and Commentary, T.N. Ganapathy (ed. and transl.), Quebec 2013, pp. 1521-1710.

\footnotetext{
${ }^{36}$ P. Nandakumar, op. cit., p. 75.

37 T.N. Ganapathy, Preface [in:] The Yoga of Siddha Tirumular..., p. XVIII.
} 
Avalon A., The Serpent Power being the Shat-Chakra-Nirūpana and Pādukā-Panchakā, Madras 1950.

Balachandran M., Sree Narayana Guru. A Comprehensive Study, Varkala 2015.

Bhāskaran T., Śrīnārāyaṇaguruvinte Sampūrnakrtikal, Kozhikode 2015.

Brooks D.R., Auspicious Fragments and Uncertain Wisdom: The Roots of Śrīvidyā Śākta Tantrism in South India [in:] The Roots of Tantra, K.A. Harper, R.L. Brown (eds.), Albany 2002, pp. 57 76.

Devī Māhātmyam. In Praise of the Goddess, transl. and com. D. Kālī, Delhi 2010.

Dyczkowski M.S.G., The Doctrine of Vibration. An Analysis of the Doctrines and Practices of Kashmir Shaivism, Delhi 1987.

Ganapathy T.N., A Curtain Raiser [in:] The Yoga of the 18 Siddhas. An Anthology, T.N. Ganapathy (ed.), Quebec 2004, pp. 1-9.

Ganapathy T.N., Life Sketches of the Siddhas [in:] The Yoga of the 18 Siddhas. An Anthology, T.N. Ganapathy (ed.), Quebec 2004, pp. 11-45.

Ganapathy T.N., Preface [in:] The Yoga of Siddha Tirumular. Essays on the Tirumandiram, T. N. Ganapathy, K.R. Arumugam, G. Anand (eds.), Quebec 2006, pp. XV-XXIV.

Ganapathy T.N., The Tirumandiram. Volume 6. Translation and Commentary [in:] The Tirumandiram. Translation and Commentary, T.N. Ganapathy (ed. and transl.), Quebec 2013, pp. $1715-1851$.

Ganapathy T.N., The Tirumandiram. Volume 9. Translation and Commentary [in:] The Tirumandiram. Translation and Commentary, T.N. Ganapathy (ed. and transl.), Quebec 2013, pp. 2977-3450.

Ganapathy T.N., The Twilight Language of the Tirumandiram [in:] The Yoga of Siddha Tirumular. Essays on the Tirumandiram, T.N. Ganapathy, K.R. Arumugam, G. Anand (eds.), Quebec 2006, pp. 295-338.

Ganapathy T.N., The Yoga of Tirumandiram [in:] The Yoga of Siddha Tirumular. Essays on the Tirumandiram, T.N. Ganapathy, K.R. Arumugam, G. Anand (eds.), Quebec 2006, pp. 157-241.

Goswami S.S., Layayoga. The Definite Guide to the Chakras and Kundalini, Vermont 1999.

Israel H., Religious Transactions in Colonial South India. Language, Translation, and Making of Protestant Identity, New York 2011.

Jayakumar V., Sree Narayana Guru. A Critical Study, New Delhi 1924.

Kandaswamy S.N., The Tirumandiram. Volume 8. Translation and Commentary [in:] The Tirumandiram. Translation and Commentary, T.N. Ganapathy (ed. and transl.), Quebec 2013, pp. 2327-2966.

Kumar P., Śaktism in India (With Special Reference to the Purānic Literature), New Delhi 2012.

Kumaran M., The Biography of Sree Narayana Guru, Varkala 2014.

Nair T.B., Jñānakkațal (Malayalam Mertical Version of Jnanakkovai, in Tamil), Trivandrum 1974.

Nandakumar P., Tirumūlar Dhyānam-20 (Meditation) [in:] The Yoga of the 18 Siddhas. An Anthology, T.N. Ganapathy (ed.), Quebec 2004, pp. 75-94.

Nāyar B., Śrīnārāyaṇa Gurudēvakrtikal. Sampūrṇa Vyākhyānam, vol. 1, Thiruvananthapuram 2010.

Nāyar C.K.G., Tirumūlanāyanār Tirumantram, Kottayam 2007.

Pandit B.N., Specific Principles of Kashmir Śaivism, New Delhi 1997.

Ponnuswamy S., Sekkizhar's Periya Puranam, Chennai 2015.

Prasād M.N., Narayana Guru. Complete Works, New Delhi 2006.

Prasād M.N., Nārāyaṇaguru. Svānubhavagīti, Varkala 2002.

Ramachandran T.N., The Tirumandiram. Volume 4. Translation and Commentary [in:] The Tirumandiram. Translation and Commentary, T.N. Ganapathy (ed. and transl.), Quebec 2013, pp. 1053-1512.

Ramanujan A.K., Speaking of Śiva, New Delhi 1973. 
Shomerus H.W., Śaiva Siddhānta. An Indian School of Mystical Thought, New Delhi 2000.

Siddhalingaiah T.B., Pāmbātțiccittar. Selections from Dance, oh! Snake! Dance [in:] The Yoga of the 18 Siddhas. An Anthology, T.N. Ganapathy (ed.), Quebec 2004, pp. 485-513.

Siddhalingaiah T.B., Selections from Kudumbaiccittar's Poems [in:] The Yoga of the 18 Siddhas. An Anthology, T.N. Ganapathy (ed.), Quebec 2004, pp. 321-354.

Silburn L., Kundalinī. The Energy of the Depths. A Comprehensive Study Based on the Scriptures of Nondualistic Kasmir Saivism, Albany 1988.

Somasundaran P.S., Maccamuni. Kāraña Jñānam-10. (Source of Wisdom) [in:] The Yoga of the 18 Siddhas. An Anthology, T.N. Ganapathy (ed.), Quebec 2004, pp. 155-167.

Somasundaran P.S., The Tirumandiram. Volume 7. Translation and Commentary [in:] The Tirumandiram. Translation and Commentary, T.N. Ganapathy (ed. and transl.), Quebec 2013, pp. 1861-2322.

Subamanian S., Arunachalam T.N., The Tirumandiram. Volume 10. Appendices, Glossary, Selec Bibliography, Index [in:] The Tirumandiram. Translation and Commentary, T.N. Ganapathy (ed. and transl.), Quebec 2013, pp. 3455-3832.

Śabdatārāvali (Malayālam Nighaṇtu), K.G. Padmanābhapiḷa (ed.), Kottayam 2011.

Tagare G.V., Śaivism. Some Glimpses, New Delhi 1996.

Tirumantiram by Tirumular, B. Natarajan (transl. and ed.), Madras 1991.

Venkataraman T.V., The Tirumandiram. Volume 1. Translation and Commentary [in:] The Tirumandiram. Translation and Commentary, T.N. Ganapathy (ed. and transl.), Quebec 2013, pp. 1-406.

Venkataraman T.V., The Tirumandiram. Volume 2. Translation and Commentary [in:] The Tirumandiram. Translation and Commentary, T.N. Ganapathy (ed. and transl.), Quebec 2013, pp. 409-650.

Venkataraman T.V., The Tirumandiram. Volume 3. Translation and Commentary [in:] The Tirumandiram. Translation and Commentary, T.N. Ganapathy (ed. and transl.), Quebec 2013, pp. 659-1050.

Yati N.C., Narayana Guru, New Delhi 2007. 